\title{
PANDEMIC AT THE POLLS: AN ANALYSIS OF THE DECISION TO CONTINUE THE 2020 REGIONAL HEAD ELECTION
}

\author{
IN THE NEW NORMAL ERA
}

\author{
Ratna Rosanti \\ Universitas Airlangga \\ ocha2608@yahoo.co.id
}

Received: 30 June 2020 ～Reviewed: 30 June 2020 | Accepted: 4 August 2020

\begin{abstract}
ABSTRAK
Artikel ini secara khusus akan memberikan penilaian awal dari banyak risiko yang mungkin dapat ditimbulkan oleh pandemi Covid-19 jika pemilu tetap diselenggarakan dan bukan tidak mungkin jika pemilu tetap dilanjutkan di masa pandemik akan jauh dari unsur adil, jujur dan transparan bahkan membahayakan keamanan dan keselamatan pemilih di Tempat Pemungutan Suara. Seiring dengan hal tersebut, munculnya era baru selama pandemi atau yang disebut New Normal di mana setiap orang harus berperilaku baru dalam kehidupan sehari-hari dengan memprioritaskan aspek kesehatan tentunya akan memiliki pengaruh yang signifikan dalam pelaksanaan pemilu. Artikel ini dimulai dengan menjelaskan mengapa pemilu merupakan bagian penting dari demokrasi, dan kemudian melihat bagaimana respons pemerintah terhadap pandemi dan pemilu yang akan diadakan di era Normal Baru akan menghadirkan solusi signifikan tentang masa depan demokrasi itu sendiri. Dalam artikel ini, penulis juga merekomendasikan beberapa hal terkait penyelenggaraan pemilu selama pandemi. Temuan utama dari tulisan ini adalah: Pertama, kehadiran virus itu sendiri dapat secara langsung mencegah pemilih memberikan suara mereka di TPS dan bahkan mempengaruhi keseluruhan tingkat partisipasi pemilih. Kedua, ada konsekuensi menunda secara resmi penyelenggaraan pemilu yang bervariasi berdasarkan jenis rezim (nasional atau lokal). Ketiga, beberapa elemen dalam siklus pemilu dapat dipengaruhi oleh pandemi.
\end{abstract}

Kata Kunci: Demokrasi, Pemilihan, Resiko Pemilihan, Pandemik, Covid-19

Korespondensi:

Universitas Airlangga

Jl. Airlangga No.4 - 6, Airlangga,

Kecamatan Gubeng, Kota SBY, Jawa Timur

E-mail: ocha2608@yahoo.co.id 


\begin{abstract}
This article will specifically provide a preliminary assessment of the many risks that the Covid-19 pandemic might pose if elections continue to be held and it is not impossible that elections continued during the pandemic will be far from being fair, honest and transparent even endangering the security and safety of voters at the Polling Stations. The emergence of a new era during the pandemic called New Normal where everyone must behave new in everyday life by prioritizing aspects of health will certainly have a significant influence in the implementation of elections. The method used is the study of literature. The literature used in this study includes all literature, news coverage and reports relating to the holding of the elections including previous books and articles that discuss the holding of elections during a pandemic. This paper begins by explaining why elections are an important part of democracy, and then looks at how the government's response to the pandemic and elections that will be held in the New Normal era will present significant solutions about the future of democracy itself. In this paper, the author also recommends several things related to the holding of elections during the pandemic. The main findings of this paper are: First, the presence of the virus itself can directly prevent voters from casting their votes at the polling stations and even affect the overall level of voter participation. Second, there are consequences of formally delaying the holding of elections which vary by type of regime (national or local). Third, some elements in the electoral cycle can be affected by the pandemic.
\end{abstract}

Keywords: Democracy, Election, Election Risk, Pandemic, Covid-19

\title{
INTRODUCTION
}

The Covid-19 pandemic that struck almost all countries in the world caused a collapse. Not only does it cause a crisis situation in almost all aspects of life, such as the economic and business sectors, tourism, education, and politics. This terrible pandemic has caused hundreds or even thousands of people to die within a day. Then, what about Indonesia? The impact of the COVID-19 pandemic on people's lives is enormous. Until Tuesday, July 28, 2020, there have been 100.303 positive confirmed cases in Indonesia with 4.848 people died because of Covid (see the daily development of the COVID-19 pandemic in Indonesia on the Ministry of Health website, https://covid19.kemkes.go.id). The distribution of Covid-19 occurred throughout Indonesia with Java as the largest area affected. Community mobility in various provinces has also become limited because the government has implemented Large-Scale Social Restrictions (PSBB), roadblocks by security forces, and reduced market hours and other business sites. This resulted in hampered economic and social activities.

Minister of Manpower of the Republic of Indonesia, Ida Fauziyah said that around 2.084.593 workers nationwide had been laid off and laid off. Of this total, 1.546.208 people work in the formal sector and 538.385 in the informal sector (Republika, 2020). According to 
the Ministry of Manpower, around 85 percent of workers were laid off because their offices/companies were not operating due to the implementation of the PSBB by the local government. The majority of these workers work in the fields of micro small and medium enterprises (MSMEs), tourism, transportation, and manufacturing. In addition, the regional quarantine /lockdown policy in other countries also appeared to affect various business units in Indonesia because these companies had difficulties in importing raw materials for production and exporting their products to other countries.

The economic impact of the COVID-19 pandemic does not stop there. Minister of Finance, Sri Mulyani conveyed several national economic scenarios in the current COVID-19 pandemic situation (Tempo, 2020). Before the pandemic, the government projected domestic economic growth in the 2020 APBN at 5.3 percent. The projection can change to 2.5 to -0.4 percent with inflation rates between 3.9 and 5.1 percent after calculating the estimated impact of a pandemic in Indonesia.

Furthermore, the SMERU Research Institute (2020) recently released the results of a simulation of the impact of the COVID-19 pandemic on poverty levels in Indonesia (Asep Suryahadi dkk, 2020). In contrast to the ideal projection of economic growth in 2020 of 5 percent, the study explained that the figure would decrease from 4.2 to 1 percent due to the impact of the spread of COVID-19. So, if economic growth in Indonesia is only corrected to 4.2 percent, the poverty rate is in the range of 9.22 percent to 9.71 percent. This means that the number of poor people in Indonesia is likely to increase by 1.3 million or a total of poor people to 26.09 million. If the economy only grows between 1.2 and 1 percent, the poverty rate is estimated to rise between 12.21 to 12.37 percent. The number of poor people rose by 8.03 to 8.45 million or the total number of poor people in Indonesia to be between 32.82 and 33.24 million. Looking at the economic situation and projections, the Covid-19 pandemic seems to have developed far from a health crisis that is slowly escalating into a socio-economic crisis.

In addition to having an effect on the economy and health, the Covid-19 pandemic also caused a political crisis and several elections were postponed in several countries. Delayed elections are not only on a national scale like a presidential election, but also on a local scale such as a regional head election. More than 40 countries in the world, including Indonesia, have postponed elections due to Covid-19. On the one hand, there is a risk that must be borne 
behind the delay. However, this moment is the right time to rethink effective solutions, if in the future direct elections cannot be carried out due to non-natural disaster factors. The Covid19 pandemic also had an impact on democratic parties in various parts of the world. According to the International Institute for Democracy and Election Assistance (International IDEA) records, as of the first week of April, as many as 47 countries in the world have postponed the election stage.

Based on Global Overview Of Covid-19 Impact On Elections published by IDEA International, it is mentioned that delays were carried out in various countries in Europe, Asia, and Africa. (IDEA International, 2020) Presidential elections, mayors, parliamentarians, and referendums on various policies cannot be carried out in accordance with the stipulated time. Europe is the region with the most postponed elections compared to other regions. From March 1 to April 8, there are 17 countries in Europe have decided to postpone the elections. Italy is one of them. The parliamentary reduction referendum scheduled for 29 March 2020 was decided to be postponed until an undetermined time. Italy plans to reduce MPs from 630 to 400 and senate members from 315 to 200. However, the rapid increase in positive cases of Covid19 was the reason for delaying the referendum. Entering the second week of April, more than 140,000 people have been infected with Covid-19 in Italy.

Still according to International IDEA in its report (IDEA International, 2020), it was stated that in addition to the referendum, postponement of local elections was also carried out by some countries in Europe, one of which was Austria. The general election in Vorarlberg, which was originally to be held on March 15, must be postponed until an undetermined time. On the Continent, seven countries were postponed the election. Parliamentary elections in Ethiopia on 29 August are one of them. Until April 14, the World Health Organization (WHO) noted there were 74 positive cases of Covid-19 in the country.

The same condition is experienced by 12 countries in the Americas. In the United States, several local elections scheduled for March to May 2020 have been postponed. The United States is currently struggling to overcome the Covid-19 pandemic. According to WHO records, more than 550.000 positive people infected with the disease due to this new corona virus. However, there has been no decision to postpone the presidential election which will be held on 3 November. 
In Asia, eight countries have also decided to postpone the general election. Postponement of parliamentary elections by Iran, Syria and Sri Lanka. While in Indonesia, the postponement of the elections was also carried out for the regional head elections that will be held on 23 September. So how about the consequences? the postponement of the general election certainly has several consequences for election organizers and participants. Consequences must be taken in order to maintain the quality of the election administration.

For the organizers, the impact that must be felt is the increased budgetary needs. If the selection phase must be repeated from the beginning, of course it must be accompanied by additional budget that had previously been used. Another obstacle is the number of permanent voter lists. If the election is postponed, the number of people entitled to vote will change. In regional elections in Indonesia, for example, the General Election Commission (KPU) must readjust the voter list for residents aged 17 years or who are married according to the delay schedule set. The impact of the delay was also felt by election participants, both political parties and individual candidates. For countries or regions that postpone before the campaign starts, this will certainly be a good opportunity for election participants to disseminate to the public at large.

However, for countries or regions that have entered the campaign period, the postponement of the election will certainly have an impact on the political costs incurred by election participants. Moreover, if the delay is carried out for up to one year. The campaign needs to be repeated near the time of the election in order to have an electoral effect on the election participants. While in terms of voters, the impact of election delays that must be anticipated is the decline in voter participation. Massive socialization must be done so that the public knows the election schedule. In addition, the KPU also needs to provide a sense of security for the public in choosing. Because, even though the Covid-19 transmission would later be successfully overcome, the fear of visiting the crowded spots, including polling stations, could still plague the community.

In Indonesia, KPU as Electoral Management Body has indeed decided to postpone the election with a number of options. The first option is to postpone the election which will be held on 9 December 2020, the same date as the 2015 simultaneous local elections. This option was proposed with consideration of the Covid-19 emergency response period set for May 29. 
While the other options are March 17, 2021 or September 29, 2021. The second and third options give more time for preparations to be held after Covid-19 has been successfully overcome.

On April 14, the Government and the House of Representatives of Indonesia agreed to postpone the elections on 9 December. This means that massive socialization must take place since June if the Covid-19 emergency response period ends in May. This information must be immediately known by the community up to the village level in order to be able to use their voting rights at the end of this year. Behind many of consequences that must be borne, this pandemic can be a good time to find alternative solutions and can be used in the long term if at any time the general election must be stopped due to non-natural disasters. In this case, there are several countries have used alternative solutions to hold elections in the midst of the Covid19 pandemic, one of which is through the post.

However, this can only be done in countries that have prepared infrastructure to maintain the security of ballot security. Option to use the post in the election in the middle of the Covid-19 pandemic, one of which was carried out by the Bavarian region, Germany, in March. This was done to reduce the crowd. Elections by post do have risks in terms of the security of ballot security. In addition, the election through this model also requires the activeness of voters to return the ballot by post to the election organizer. This option also requires logistical and security guarantees for ballots from the time they are sent to the voter until they are received again by the election organizer. However, this can be an alternative solution that can be prepared if one day the election must be postponed again due to non-natural disasters.

In addition to election by post, electronic voting can also be an alternative solution. This proposal was raised in a hearing between the Indonesian Parliament, the KPU and the Ministry of Internal Affairs. However, this method cannot be done because there is no supporting infrastructure. Electronic voting has become a matter of discourse along with the development of democracy in Indonesia. Although, based on Kompas Research and Development poll at the end of December 2019, as many as $76.2 \%$ of the public still wanted direct elections via ballot. However, there is no harm in starting to prepare this step as an alternative solution if direct elections using ballots must be abolished due to disasters or other 
factors. However, the transition to democracy through elections is an important agenda that must not be ignored about human values. However, finding alternative steps also needs to be taken as a guide for Indonesian democracy if faced with a similar situation.

As the result of hearing Commission II with the Ministry of Home Affairs, KPU RI, Bawaslu RI and DKPP RI (on May 27, 2020), on December 9, 2020, there's 270 regions with details of 9 provinces, 224 districts, and 37 cities in Indonesia held a simultaneous Regional Head Election (Tirto, 2020). The main concern was that elections were held during the COVID19 global pandemic, where cases of infected people and the number of deaths increased at dramatic rates, because many areas became red zones because the number of people exposed to Covid-19 was very high. Base of the Data from Gugus Tugas Covid-19 in Indonesia, when this article is writing, more 100.303 people were positive for Covid-19 and 4.848 people died (see Ministry of Health website, https://covid19.kemkes.go.id).

The increasing number of patients then raises significant concerns about health risks for voters especially as the election still uses traditional voting methods, and the possibility of a biased vote will certainly jeopardize the ability for the state to guarantee genuine and transparent elections. Outside Indonesia, several countries continue to carry out elections under the shadow of the Corona pandemic. Republic of Korea has given an example by continuing to carry out the voting process on April 15,2020 but by continuing to be supported by measures to prevent the spread of Covid-19 so that voters are still given a sense of security and comfort in participating in elections, so that the number of voters participating is more than $66 \%$ and is the highest in the last three decades. Besides Korea, Mali also continued to hold its first round of elections on March 29, 2020 with a very low turnout because it also coincided with the announcement of corona virus deaths for the first time.

After the first round was over, elections in Mali continued with the second round on April 19. Mali is different, it also happened in France which canceled the second round of local elections which was supposed to be held on March 29, 2020, and in the first round election on March 22, 2020, the turnout was much lower than in the previous election. The emergence of different approaches to managing elections during the pandemic ultimately raises a number of questions about the risks of implementing democracy faced with external threats in the form of the spread of Covid-19 as experienced in almost all parts of the country including Indonesia. 
In this article, the authors argue that the Covid-19 pandemic has a significant risk to the ability of countries to guarantee genuine and transparent elections, and that without properly considered steps, holding elections can have a significant impact on protection public health. and the integrity of the election itself.

In this article, the author illustrates how pandemics can influence the important elements that shape the electoral cycle and consider different steps to reduce electoral risk from a pandemic, including cancellations, delays, postal voting, and electronic voting. From this phenomenon the author is interested in further researching and analyzing the holding of elections in the New Normal era, with the formulation of the main problem, "How to design the holding of elections during a pandemic and how to realize the 2020 local elections in Indonesia during the pandemic?" The legal theory that the author uses in this article is a theory of constitutional democracy as a result of reforms that implementation Indonesian constitutional system based on law is not only power.

The author also uses the theory of the legal system in which each element of the legal system namely the substance, structure and culture of the law works together so that it can influence the level of public participation in elections. In addition, theory the operation of the law we can use it for analyze how regulation regulation works in any society influence and inhibit improvement community participation in local elections when regulation it is applied in the community. In the opinion of Gaventa and Valderna as stated in Dr. Siti Irene Astuti Dwiningrum asserted that public (community) participation has shifted the concept of participation towards a concern with various forms of citizen participation in policy making and decision making in various key rumors that affect the lives of community members.

Public (community) participation become one of the indicators in application democratization in Indonesia, public participation in simultaneous local elections as one of the characteristics of the country democracy is very urgent fulfilled because the level of public participation becomes dependent variable in improving quality democracy in Indonesia especially democracy constitutional. Public participation rate at general elections and elections simultaneously influenced by various factors, including: political participation, diversity of voters, election organizers, Public satisfaction on government and electoral system and 
candidate figures. In addition to the theory of constitutional democracy theory, the authors also use decision making theory to analyze this problem.

The author uses this theory because human beings are essentially decision-makers (decision-making man), decision-making, the determinant of a choice of a number of choices, including in this case is to decide the election is still running or temporarily stopped. Decision making occurs at any time throughout human life. Human life is life that is always filled with decision-making events. A similar statement was made by Suharnan that every day people are involved in the act of making a decision or decision making, maybe even it must be done several times. Starting from complex problems and requires a lot of consideration and depth. Decision-making activities are often done by people whether they realize it or not, because in daily life a person will find many situations that are uncertain (uncertainty). Moergan and Celrullo define a decision is a conclusion reached after consideration, which occurs after one possibility is chosen, while the other is ruled out. Meanwhile, according to Baron and Byner explaining decision making is a process through a combination of individuals and groups and integrating existing information with the aim of choosing one of the various possible actions, decision making as a process of evaluating existing choices to get results which are expected.

Then, according to Terry, decision making is choosing alternative behaviors from two or more alternatives. Furthermore, according to Siagian, essentially decision making is a systematic approach to a problem, gathering facts and data, determining the mature of the alternatives faced, and taking the most appropriate action. Based on the above understanding, it can be concluded that decision making is a thought process in the form of a choice between a number of alternatives used as a determinant of a number of choices, and is reached after a consideration is influenced by cognitive, analytical, and experience to solve the problem at hand. Decision making often occurs both consciously and unconsciously, based on the collection of facts and data, as a decision maker made in order to take appropriate action.

The method used is the study of literature, where the sources of literature are used to compile a research framework, a tool to analyze as well as to obtain data. The literature used in this study includes all literature, news coverage and reports relating to the holding of the General Elections including previous books and articles that discuss the holding of elections during a pandemic. Data collection until the analysis process starts from April 2020. 


\section{DISCUSSION}

Since 2005 in Indonesia there has been a new democratic procedure to replace and fill the position of Regional Head, conceptually called "Pilkada". In the scenario, it is imagined that the citizens need the elections. Through the elections, residents in an area can freely support a person to become a Regional Head, in accordance with their diverse aspirations, and according to their respective rationality. In this regard, each actor who is a candidate is required to make political commitments, as another interpretation of the importance of the 'social contract', to fight for the aspirations of the people, whose main issue is usually not far from issues of people's welfare and sense of social justice. Election as a political event, in fact is a stage that shows a dramaturgy. The problem is that the people as the owners of democratic political sovereignty do not need dramaturgy which positions them only as passive spectators. The regional election is idealized to be fair, and the principle of justice is meant not only in the framework of no favoritism from the organizers, but also must be fair in treating the people as holders of sovereignty.

The local election is actually a means for the people to choose the best leader for the people and their regions. It is hoped that through the regional elections regional leaders will be able to meet the expectations of the majority of the people, accelerate regional economic growth, improve welfare and maintain the sovereignty of the people with dignity. This people's expectations also demand big changes that are manifested in policies that are pro-people.

\section{Elections and Democracy}

Election is a mainstay feature of democracy (Ginsburg and Huq 2018). Elections are important because they provide the main mechanism by which political leaders are elected and held accountable and through elections also individuals participate in state government (see Dahl 1971; Lijphart 1999; Lindberg 2006, Landman 2013; Webler and Tuler 2018; Pzreworski 2019). The ability of almost all countries to conduct elections is undeniably always supported by the protection of human rights such as freedom of movement, freedom of association, freedom of association, and freedom of speech (Dahl 1971; Landman 2013). Elections here also function in aggregating the interests of citizens and mediating the relationship between citizens and the government in several different dimensions: (1) in electoral units (local, regional and national), (2) branches of government (executive and legislative), and (3) time 
and type of election. The increasing number of countries that recognize themselves as democracy during the 'third' and 'fourth' democratic waves since the 1970s (Huntington 1991; Doorenspleet 2005; Landman 2013) has been proven by elections held in all parts of the world each year even at the time of their occurrence pandemic.

This is where the leaders, government and democracy activists in the future must focus more on steps to reduce the risks that might occur during the process of holding elections, including even the worst. In 2020, 28 countries had held national elections in which more than 88 million voters had participated in the elections, while at the height of the pandemic between March and May 2020 there were 22 elections scheduled (Table 1). Then between April and October 2020, more than 30 national elections have been scheduled, and several local and state elections, while the world's concern is the United States Presidential Election is scheduled to be held on November 3, 2020.

Table 1. Elections During Covid-19 Pandemic, March-May 2020

\begin{tabular}{lcc}
\hline \multicolumn{1}{c}{ Country } & Type of Election & Date of Election \\
\hline Israel & Parliamentary elections & 2 March 2020 \\
\hline Taiwan & Kuomintang Chairperson Election & 7 March 2020 \\
\hline France & Local elections & 15 March 2020(a) \\
\hline Germany & Local elections (Bavaria) & 15 March 2020 \\
\hline Moldova & Local elections (Hâncesti) & 15 March 2020 \\
\hline Dominican Republic & Municipal elections & 15 March 2020 \\
\hline United States & Primaries (Arizona, Florida, & 17 March 2020 \\
& Illinois) & \\
\hline Vanuatu & General elections & 19 March 2020 \\
\hline Zimbabwe & Municipal elections & $14-22$ March 2020 \\
\hline Poland & By-election & 22 March 2020 \\
\hline Guinea & Constitutional referendum & 22 March 2020 \\
\hline Canada & Shoal Lake 39 council elections & 26 March 2020 \\
\hline Mali & General elections & 29 March 2020 \\
\hline Australia & Local elections (Queenstown) & 29 March 2020 \\
\hline Switzerland & Local elections (Luzern) & 29 March 2020 \\
\hline United States & Presidential primary (Wisconsin) & 7 April 2020(a) \\
\hline South Korea & Legislative elections & 15 April 2020 \\
\hline Russian Federation & Referendum & 22 April 2020(b) \\
\hline Chile & Referendum & 26 April 2020(b) \\
\hline Kazakhstan & Kazakh House of Representatives & 30 April 2020 \\
\hline Bolivia & hamber of Deputies, Senate, & 3 May 2020(b) \\
\hline (a) Partially postponed (14 states in the US and Puerto Rico postponed primary elections) \\
\hline
\end{tabular}


(b) Postponed

Source: Election Guide, available at http://www.electionguide.org/digest/post/17597/

The holding of elections in the Covid-19 pandemic was a global concern. The condition of each country is certainly different, but all consider the same thing, namely the safety of voters, election participants and organizers. Various international democratic institutions gave their views and input for the holding of elections in the Covid-19 era. As the New Normal approach is being carried out by a number of countries during the Covid-19 period, it becomes the same need to formulate New Normal in the technical implementation of the 2020 regional elections in Indonesia. International IDEA made a written document regarding the considerations surrounding elections in Covid-19. Conveying three main considerations in planning elections in Covid-19, namely the significance of the constitutionality of elections, alternative campaign mechanisms and alternative long-distance voting methods. Regarding the legitimacy of the administration, there are four things that need to be considered, namely: the loss of votes, demands for political opportunism, the effect on voter participation and the impact on the substance of the campaign. Other considerations on the five risks as the implications. There are: the reputation of decision makers, political, financial, operational, and legal framework.

Not only International IDEA but also IFES (International Foundation for Electoral Systems) makes the document more focused and in-depth aspects of health in the administration of elections. There are four recommendations for all technical stages of selection:

1) Communicate and coordinate with competent public health authorities in conducting risk analysis, decision making, planning, and implementing risk mitigation strategies effectively;

2) Prevent or reduce direct interaction between individuals: Apply rules of safe physical distance, respiratory hygiene, use of Personal Protective Equipment (PPE), and, if possible, adopt safe remote devices and mechanisms. ;

3) Prevent or reduce surface contamination and objects used in general. Applying the use of PPE such as face masks and respiratory hygiene; and, if possible, adopt a "touchless" mechanism; and 
4) Prevents or reduces exposure of people to contaminated surfaces or objects. Encourage hand sanitation using soap and water, or alcohol-based solutions; encourage all present not to touch the mouth, nose and eye area; frequently disinfects surfaces and objects used by many people; implementing the use of PPE; if possible, use a no-touch mechanism.

The Kofi Annan Foundation also expressed his views on this and conveyed seven main principles in the election process during the Covid-19 pandemic. The seven principles are:

1) A firm grounding in the law. Where the national legal framework does not anticipate such a situation, necessary changes should be formally adopted, consistent with international obligations.

2) Broad political support. Without this, measures may be perceived as a strategy for political gain by incumbents, which can subvert the public trust that is essential to address the health crisis.

3) Clear and transparent communication to the public. Voters will need to understand what measures are being considered, by whom, and on what grounds. The media has a crucial role to play in preventing democratic erosion by monitoring policy and shining a light on critical issues.

4) Proportionality. It means how voters are registered, ballots are cast, or votes are tabulated - should be reasonable and proportionate to the risk posed by the coronavirus.

5) Based on the best available technical information. Choosing suitable, proportionate measures requires not only legal certainty and political buy-in but also subject matter expertise. The relevant experts, including electoral experts, should be consulted as early as possible.

6) Time-bound. Insight of any emergency measures should be clearly set out. This is particularly relevant in the case of a postponement of elections, which should not be openended. Where it is not possible to set a new date, there should be clarity and agreement on how to determine when risks have been overcome.

7) Mindful of particularly affected groups. Some citizens will require special consideration at this time to ensure free, fair, and safe elections. These include those who are in hospitals or isolation due to the virus; health care workers; law enforcement and military personnel 
assisting in the crisis; and traditionally marginalized groups, such as women, persons with disabilities, the elderly, refugees and migrants, minority groups, and others.

\section{Decision to Proceed Simoultan Election of Regional Head 2020 During Pandemic}

Meeting and hearing with Commission II with the Ministry of Home Affairs, KPU RI, Bawaslu RI and DKPP RI on May 27, 2020 produced three conclusions related to simultaneous election delays. The three conclusions are:

1) Mutual agreement continues the selection process simultaneously;

2) Approving the draft KPU Regulation (PKPU) regarding the revision of stages, programs and schedules which will start on June 15, 2020;

3) The need for additional budget to be immediately submitted in detail and will be discussed.

The first conclusion cannot be separated from the letter of the Chairman of the Task Force for the Acceleration of Handling Covid-19 (Gugas) Number: B-196/KA GUGAS/PD.01.02/ 05/2020 dated May 27, 2020. The contents of the letter explaining the implementation of simultaneous elections in 2020 which can be delayed can be continued with conditions are implemented according to the Covid-19 protocol at each stage. These inputs moved from the condition that no one could predict when the Covid-19 pandemic ended.

The letter in the election administration process is the same as the explanatory document from the Ministry of Education or Ministry of Education and Culture if there is an allegation of the validity of the candidates' elections. If in the health examination stage, the candidate pair of regional head candidates will be the same as the documents resulting from the health examination by the Health Examination Team. KPU makes explanatory documents from competent institutions or parties a consideration. With the results of the Hearing with Commission II of the People's Representative Council of Indonesia, KPU RI immediately finalized and decided on a number of technical arrangements for implementation. Since the end of March, intense discussions and various technical adjustments have been made. These adjustments become necessary as a form of election service that gives a sense of security and comfort to all parties. Substantially, this adjustment is in line with changes in life order towards New Normal. 
What's New Normal? The term New Normal became a new mantra as a form of human adaptation to normalize life in Covid-19. The two words are generic, easy to digest and at the same time be understood by various walks of life, especially ordinary people. Easier than the term Protocol Covid19. Including introducing new things in the technical implementation of simultaneous local elections in 2020. The term New Normal came to the fore now after Hans Kluge (WHO European Regional Director) mentioned the first time during a press conference on April 16, 2020. He delivered the transition guidelines for countries in Europe in the face of the Covid-19 pandemic. Since then every mention of New Normal has been based on the transition guidance for Covid-19.

Though the term New Normal was first mentioned by Roger Mc Namee in early 2003. His digital footprint can easily be found in the publication of his interview on April 30, 2003 on the website of the magazine Fast Company. The following year (2004) Roger and David Diamond wrote a book entitled New Normal. Roger called New Normal a new landscape in the technology investment business that he has been in for 38 years. He is known as a veteran in Silicon Valley and was a mentor to Mark Zuckerberg when developing Facebook. His view as an antithesis of the dotcom business recession that occurred in America in the late 19902000s. Roger also redefined life in terms of time, money, leadership and of course technology.Thus, the use of the term New Normal is not appropriate if it is positioned solely for the transition policy model as explained by Hans Kluge. It can be used for all things related to efforts to generate new normalcy, including handling Covid-19 with the context of different conditions. So that the New Normal policy in Europe can be adopted or different from the New Normal policy in Indonesia or other countries.

There are at least five things relevant to the new normalcy that would be realized in the current Covid-19 from the results of the Roger Mc Namee interview published on the fast company page:

First, New Normal is performed because old normal can no longer be used. Old lifestyle such as talking at close range and not wearing a mask outside the home can no longer be done. The new lifestyle requires talking between people to be distant and keep using masks. Adjacent and shaking hands as a form of close and polite relations can no longer be done. In this context, reporting about New Normal failed in South Korea with a re-emergence of the mistaken Covid- 
19 case. It is very likely that this happened because the community re-applied the old normal lifestyle. New Normal once again means a change in the new way of life that discipline is applied to. If undisciplined, there is a potential for conditions to recur.

Second, New Normal begins when the old normal crisis condition subsides and so that it is no longer trapped or repeated the second old normal crisis. In the context of Covid-19, New Normal is the solution to keep active case charts low and under control. Total discipline is needed to prevent the second wave from happening. New Normal scenarios can also be an effort to accelerate the easing of the crisis that is happening.

Third, New Normal can only be effective for people who want to change or want to make adjustments . People who still hold on to life with old normal have the potential to be "excluded". Here it is important public communication efforts to make New Normal effective in society.

Fourth, technology is used to create competitive advantage. The past of technology is a non-core activity, now technology is truly interwoven into the social fabric. Today people's lives are increasingly digital. Digitalisation of life becomes a new field that is open to anyone who puts forward achievements not prestige and popularity.

Fifth, the hope of a New Normal effort is simple for Roger Mc Namee, "Make your life a little better".

\section{How to Proceed Simoultan Election of Regional Head 2020 in Pandemic}

The main keyword to continue the simultaneous selection of 2020 is the Covid-19 protocol at each stage. One of the targets for holding simultaneous elections is that there are no voters, officers and participants who have been exposed or died due to Covid-19. The dark event of the death of hundreds of election officials in 2019 became a human experience that must not be repeated. At present the KPU is intensively coordinating with Gugas and the Ministry of Health to formulate the Covid-19 protocol at each stage. Adjustments pay attention to three things: regulatory aspects, technical aspects and aspects of socialization or education. 
The regulatory aspect involves adjustments to limitations that do not exceed or change the provisions of the Election Law. KPU regulations (PKPU) regarding stages, programs and schedules are being finalized. As electoral management body, KPU must carried out the harmonization of the PKPU draft with the Ministry of Law and Human Rights. Also present and giving views from Bawaslu RI, National Disaster Management Authority (BNPB RI), Ministry of Home Affairs and Coordinating Ministry for Politics, Law and Security.

KPU is also in the process of finalizing the drafting of KPU regulations regarding the governance of elections in the Covid-19 era. Each step is examined and adjusted as much as possible with the primary consideration of preventing the spread of Covid-19. However, technical adjustments do not change the existing standard. This is related to the lack of time to conduct socialization. Stages of factual verification (virtual) of prospective individuals who are directly carried out when the election continues. A total of 4.3 million voters will be confirmed of their support for 152 prospective pairs of candidates. The Election Law regulates the confirmation process must be directly to supporters as a whole (census method). Stages of matching and research (we called it "coklit") will be carried out together with virtual. There are 105 million voters who need to be confirmed. The challenge is how the brown process that minimizes 105 million voters exposed to Covid-19. If a door-to-door approach is used , 105 million potential voters are exposed to Covid-19.

For the last time there has been a tendency for people not to want to receive guests. Some news reports even featured photos of residents' homes that explicitly put up announcements and banners in front of their houses did not receive guests. The door to door work process also has the potential to not run optimally if it is still used. The Election Law does mention the existence of the Voter Data Update Officer but it does not explicitly mention that technical work must be door to door as it has been done so far. The election law only mentions updates based on improvements from the neighborhood or other designations and additional voters. The relative nomination stage can be optimally suppressed for physical distancing by limiting the registration process of prospective pairs of candidates to the determination of candidate pairs. 
The campaign stage can optimize the online or online approach more broadly and minimize the offline or offline approach. In the previous PKPU, the online approach was only limited to social media. Now it can expand to all online media covering online advertising, online news, websites, e-mail and the like. It also includes optimizing live streaming facilities or online meeting applications such as zoom, google meet and others. The stages of voting and counting are the highlight of the election. Around 101-105 million voters in 309 regencies /cities in 32 provinces will come to the polling station. Covid-19 free polling station formulations continue to be examined since the end of March 2020. The choice to reduce the number of voters per polling station so that the mass concentration is not much and the polling station duration is a consideration. Procurement of body temperature gauges, hand sanitizers, hand washing facilities are a necessity. Spraying the polling station area with a disinfectant to ensure that sterile from Covid-19 is needed. The choice of disposable punched tools surfaces in internal discussions. The procedure for inking is three alternatives, sprayed, dripped or smeared using a cotton swab.

After the identification and choice of the Covid-19 protocol at each stage, the following consequences will be an increase in the budget. The budget for the procurement of additional work tools ranging from masks to officers during work until various other tools become needs are met. Additional budget needed is more than 535 billion with detailed calculations and based on the latest polling station data from 270 regions. Human resources aspect is also a concern. Although the Covid-19 protocol is applied, it is also important to anticipate the potential exposure to officers. So adhoc body officers who have congenital diseases such as kidney, diabetes, heart disease and the like need to weigh themselves. Do you continue to be an adhoc agency officer or leave the assignment to others.

Various adjustments to the technical aspects lead to a new election management pattern that is free of Covid-19. Once formulated, received input from various parties and determined, there are still big challenges awaiting, namely socialization and education. The public has become accustomed to voting by old normal which has the high potential to spread Covid-19. 
Socialization and education factors become the next key to success. The pattern of adaptation to New Normal can be helped if the implementation of the Covid-19 protocol in the simultaneous local elections corresponds to the Covid-19 protocol in other activities.

\section{About New Normal Micro}

After the term New Normal, another term appears, namely New Normal Micro. New Normal macro scenarios in each country can vary according to the conditions of each country. But micro actually the same, namely the pattern of pyhsical distancing and maintaining body immunity. Physical distancing is now more disciplined. Discipline to keep distance, discipline to use masks, discipline to wash hands and discipline to minimize hand contact to various facilities / items in public areas. Maintaining body immunity routinely accustoms to sunbathing in the morning, regular exercise however, the workload is rational or does not work until exhaustion and maintain nutritional intake. These two things have been relatively socialized since the beginning of April but it is not easy to be carried out effectively.

South Korea, which successfully held national elections, reportedly experienced a surge in the Covid-19 case again. It needs to be echoed or public education conducts micro New Normal discipline. Actually it does not need a large fee and easy to do, namely: Discipline and example. Leaders or officials and opinion leaders need to be disciplined and set an example. Roger Mc Namee alluded to the importance of leadership in New Normal. Leaders who are not afraid to act amid uncertainty. He said Eric Schmidt (Google CEO) managed to change his behavior in New Normal so that he could play new things. Eric focused on spending time at work, not in the spotlight. Roger also gave advice to use the time for things that we really like and he did it. He is also a musician and has a band. One of the lyrics of the song he created is relevant to the question when Covid-19 ends, "... everybody has an opinion ... but, nobody knows!"

\section{How to Realize Simoultan Election of Regional Head 2020 at New Normal Era}

An unprecedented non-natural pandemic and the absence of a historical track record in the holding of elections in Indonesia that could serve as a benchmark (the Regional Election 
Law has not yet accommodating about pandemics) has been the basis for the makers of the Law and the Government to issue Perppu Number 2/2020 concerning the Third Amendment to Law Number 1 of 2015 (Chapter XVI of the Advanced Elections and Supplementary Elections).

While the underlying factor is the continued election in Indonesia on 9 December 2020 because there are several countries that have held elections during the Covid-19 pandemic. These countries include Vanuatu (March 19), Poland (March 22), Guinea (March 22), Mali (29 March), and the State of Queensland in Australia (March 29), Israel (March 2), France (March 15), Germany (March 15), Moldova (March 15), Dominican Republic (March 15), and elections in a number of the United States (March 17), local elections in Queensland, Australia (March 28) and the South Korean parliamentary elections April 15th.

In fact, continuing elections in the midst of a pandemic is not without risk. There are several challenges and risks in the holding of the elections in the Covid-19 pandemic period: safety of voters and organizers (officers), safety the soul of the indonesian people in general; economic, political, social, cultural, defense and national security issues; finance/budget; and logistics ability in finding alternatives.

For this reason, extraordinary steps or actions/thinking are needed for exceptional circumstances (because the challenges so heavy and expensive) and in order to reduce the risk of transmission:

1) Encouraging Successful Simultaneous Election of soul and safety national and local stability security (according to health protocol);

2) Expectations of voter participation are on target;

3) Ensuring that the polling station environment is safe (protection of voters and polling station officials, the area of polling stations, voting facilities (hand sanitizers, masks, helmet masks, gloves, etc);

4) Maintaining the quality of transparency in each process of election activities, particularly the crucial stages of election activities (such as: voter matching and research, Election 
participant nominations, voting and vote counting via e-recap, live streaming, electoral television programs and other electronic media);

5) Unconventional campaign methods (avoiding crowds or face-to-face/distance). Candidates can use digital technology for campaign;

6) Types, methods and means of dissemination to the public that is have access more broadly to communicate with the public.

\section{CONCLUSION}

This paper concludes three findings. First, the presence of the virus itself can directly prevent voters from casting their votes at the polling stations and even affect the overall level of voter participation. We cannot ignore that the presence of voters will certainly be seen by many as an important factor that supports the legitimacy of the election because indirectly voters give credentials to the candidates for their chosen leaders, and this can be used as a measure of the "health" of a country's democracy in general. However, in some elections democracy has experienced a secular decline in the number of voters over the last few decades, this could be further exacerbated by the pandemic. Second, there are consequences of formally delaying the holding of elections which vary by type of regime (national or local). Third, some elements in the electoral cycle can be affected by the pandemic. The easiest thing to exemplify is during campaign activities leading up to the election and when voting will be disrupted and not run normally because there must be a health protocol that must be obeyed during the New Normal era.

In response to this, the author offers three recommendations. First, the Government and House of Representative of Indonesia Republic should be able to be assertive and have high sensitivity. Don't make this emergency situation for political purposes only and take advantage of difficult conditions. Reconsider carefully and the challenges that will be faced. This election is not just a mere ceremonial event and aborts obligations. Because, the costs incurred for the elections are also not a small amount. Show the professionalism and credibility of the government to the public. So far, the people see no positive fragmentation at all of local 
democracy. Therefore, the focus of dealing with Covid-19 and restoring the economic sector is our main hope. Forcing the implementation stage, will only make the election implementation that is not optimal, even predicted many potential violations hidden. The dream is that procedural democracy will be questioned for its integrity.

Second, as Electoral Management Body, KPU RI must have any choice. KPU must prepare all good and mature planning for a healthy election (free and fair election). If this election must be held in December 2020, then the safety of the organizers, the election and participants of the election are things that must be prioritized.

Third, as Election Oversight Board, Bawaslu RI carries out strict supervision of the implementation stages stipulated by the KPU. Mapping the vulnerability of each stage in a pandemic condition also needs to be done. Politicization of social assistance funds and the potential for abuse of power by incumbents is important to be a concern of supervision. Take maximum precautions to minimize the potential for violations and decisive actions by individuals who commit election violations.

And besides that, there are also many recommendations that can be applied that work to protect voters as well as preventive measures at polling stations includes:

1) When waiting in line to vote at the polls, voters must wear face masks or face protectors;

2) Before accessing the polling station, the temperature of the voters must be checked with a non-contact thermometer; if voters are found to have a temperature of more than 37.5 Degrees Celsius, or appear to have respiratory problems or are being exposed to influenza, voters must be immediately diverted to a special polling station with a higher level of protection than the general polling station;

3) Voters must always maintain a safe distance of at least one to two meters from each other when queuing and when voting. Electoral officials can provide signs and signs strategically placed in all corners of the polling stations to assist them in maintaining such a tight distance;

4) After completing identification, voters must reassemble their face masks while still wearing gloves. Voters then cast their votes in the voting booth; and 
5) When voters will leave the polling station, they must remove the gloves and throw them into the disposal box that has been provided by officers.

\section{REFERENCES}

Asep Suryahadi, Ridho Al Izzati, dan Daniel Suryadarma. (2020). "The Impact of COVID-19 Outbreak on Poverty: An Estimation for Indonesia (Research Draft).” Jakarta.

Chu, Y., K.-P. Huang, M. Lagos, and R. Mattes. (2020). “A Lost Decade for Third-Wave Democracies?" Journal of Democracy $31 \quad$ (2): 166-181. https://doi.org/doi:10.1353/jod.2020.0029.

Dahl, Robert A. (1971). Polyarchy: Participation and Opposition. New Haven: Yale University Press.

Doorenspleet, R. (2005). Democratic Transitions: Exploring the Structural Sources of the Fourth Wave. Boulder, CO: Lynne Rienner.

http://www.euro.who.int/en/about-us/regional-director/statements/statement-invest-in-the overlooked-and-unsung-build-sustainable-people-centred-long-term-care-in-the-wake-ofcovid-19, accessed on 9 June 2020 at 11.34 WIB

Ginsburg, T., and A. Z. Huq. (2018). How to Save Constitutional Democracy. Chicago: University of Chicago Press.

Human Rights Watch. (2020). Bolivia: COVID-19 Decree Threatens Free Expression. New York: Human Rights Watch. https:/www.hrw.org/news/2020/04/07/bolivia-covid-19decree-threatens-free-expression.

Huntington, S. (1991). The Third Wave: Democratization in the Late Twentieth Century. Oklahoma: University of Oklahoma Press.

IDEA International. (2020). "Pemilu Dan Covid-19 (Makalah Teknis International IDEA 
2020).” https://doi.org/https://doi.org/10.31752/idea.2020.16.

IDEA International (Terj. Perkumpulan untuk Pemilu dan Demokrasi). (2020). "Pemilu Dan Covid-19."

IFES. (2020). “COVID-19 Briefing Series: Safeguarding Health and Elections.”

https://www.kofiannanfoundation.org/electoral-integrity/open-letter-democracy-must-not-

become-the-silent-victim-of-the-coronavirus-pandemic/, accessed on 3 June 2020 at 20.05 WIB.

https://kompas.id/baca/english/2020/04/16/covid-19-pandemic-and-lessons-on-democracy/, accessed on 4 June 2020 at 10.00 WIB.

https://kompas.id/label/regional-elections/, accessed on 4 June 2020 at 9.34 WIB.

Landman, T. (n.d). Human Rights and Democracy: The Precarious Triumph of Ideals. London: Bloomsbury Press.

—. (2018). "Democracy and Human Rights: Concepts, Measures and Relationships." Politics and Governance 6 (1). https://doi.org/10.17645/pag.v6i1.1186.

Lijphart, A. (1999). Patterns of Democracy. New Haven: Yale University Press.

Republika. (2020). "Kemenaker: Lebih Dari 2 Juta Pekerja Dirumahkan Dan Kena PHK." Republika, April 2020. https://republika.co.id/berita/q96n88377/kemenaker-lebih-dari-2juta-pekerja-dirumahkan-dan-kena-phk.

Schedler, A. (2006). Electoral Authoritarianism: The Dynamics of Unfree Competition. Boulder: Lynne Rienner.

Spinelli, A. (2020). "Managing Elections under the COVID-19 Pandemic: The Republic of Korea's Crucial Test." International IDEA Technical Paper 2/2020. https://www.idea.int/publications/catalogue/managing-elections-under-covid-19pandemic-republic-korea-crucial-test. 
Tempo. (2020). "Masa Pandemi, Sri Mulyani : Di Balik Kesulitan, Banyak Kemudahan.” Teтро, 2020. https://bisnis.tempo.co/read/1342045/masa-pandemi-sri-mulyani-di-balikkesulitan-banyak-kemudahan/full\&view $=$ ok.

Tempo. (2020). "Masa Pandemi, Sri Mulyani : Di Balik Kesulitan, Banyak Kemudahan." Teтро, 2020. https://bisnis.tempo.co/read/1342045/masa-pandemi-sri-mulyani-di-balikkesulitan-banyak-kemudahan/full\&view=ok.

Tirto. (2020). Jadwal Pilkada Serentak 9 Desember 2020, Pemerintah-DPR-KPU Sepakat. Tirto. https://tirto.id/jadwal-pilkada-serentak-9-desember-2020-pemerintah-dpr-kpusepakat-fDay

https://viryangopi.id/?p=421, accessed on 10 June 2020 at 0.35 WIB.

Zakaria, F. (2007). The Future of Freedom: Illiberal Democracy at Home and Abroad (Revised Edition). New York: Norton and Company. 